\title{
INTER-RELIGIOUS RELATIONS IN THE PERIOD OF PROPHET MUHAMMAD
}

\author{
Patmawati \\ Pontianak Steate Institute of Islamic Studies \\ patmawati@gmail.com
}

\begin{abstract}
Inter-religious relations in the period of Prophet Muhammad were running in harmony. Although there were theological differences between some religious faiths, these differences do not detract good relations. One of the written evidence of the condition of inter-religious harmony in this period was the agreement to live in peace as outlined in a treaty to respect and protect. The Madina Charter is proof that Prophet Muhammad was a religious leader as well as a political leader. The Madina Charter was born ahead of its time and can be used as a source of inspiration for building a plural society. Through the Medina Charter, the Prophet successfully organized all ethnic and religious groups in Medina, uniting them as brothers, despite different religious and ethnic backgrounds, all having the same duty to defend the State of Medina should there be an attack from outside. As a work which is based on literature research project, this article shows that the discussion of inter-religious relations in the period of Prophet Muhammad were not only supported by the works of schoolars in the fields of history and other related fields but also by the religiously based texts.
\end{abstract}

Keywords: relations, ummah, religion, Muhammad, Islam

\section{INTRODUCTION}

Inter-religious relations are the inter-relations between Abrahamic religions in the period of Prophet Muhammad, i.e. Islam, Christianity and Judaism. There are two main reasons, the theme of this study is chosen, first, the relations between religious communities have recently been in disharmony, especially in Indonesia, after Indonesia entered the milieu of reform as a new chapter that marks the process of democratization of the nation. Several areas, like Maluku and Poso, have witnessed a terrible human tragedy that drew the whole attention of the world community. The conflict which was related to SARA (ethnicity, religion, race and inter-group relations) involving two different communities has undermined all the pillars of humanity (Hasbollah Toisuta, 2007: 110). It was later realized that the disharmony was caused by external factors coming from outside the teachings of religions. Second, for 
Muslims, studying the historical events at the time of Prophet Muhammad, where the Prophet became an important actor at the time, is urgent in the implementation of religious teachings.

The behavior of prophet Mohammed has a strong influence on the life of the Muslim community as his behavior (Hadith) is part of Islamic teachings placed second after Quran. The sources of teachings may include faith, worship, morality, dakwa, education and civilization. If an issue or a case occurs in the community, and there is no legal basis found in the Quran, the judge or a mujtahid must go back to the hadith of the Prophet. (David Rashid, 1998: 35). How to idolize and emulate the Prophet in a Muslim's life is certainly based on one's knowledge of the Hadith (Prophetic traditions). The position of the hadith in Islam is based on the very important position of the Prophet as recommended and authorized by Allah (Wajidi Sayadi, 2013: 55). For example Allah expressed the advent of the Prophet as as an-Nas tukhrija li min az-ila Zhulumati an-Nur (Allah sent the Prophet to bring humans from the realm of darkness to light).

The Hadith of the Prophet serves as a guide for the Muslim community, because the revelation always guided the Prophet. So what the prophet said is ontologically assured. So, the companions of the Prophet were very attentive to his words. They collected it with great piety and related it to the future generations. After his death, the Prophet's sayings became the object of serious research so that it can be collected and recorded just like the Qur'an. Here, there is a transition from the oral to the written tradition (Mohammed Arkoun, 1996: 73). Former Minister of Religious Affairs, Mukti Ali (Speech on the Mawlid at the State Palace in 1972), cited by Endang Basri Ananda (1975: 73) said that no human being in the world has a life history (before birth until death), written and described, discussed and reviewed, like that of the Prophet Muhammad. This recognition not only comes from Islamic circles, but also researchers from outside, for example Philip K. Hitti who recognizes that the behavior of the Prophet has become a role model of millions of people on earth. Later, Hitti wrote:

"His daily conduct... has formed an order of norms adhered to by millions of people today. Nobody's behavior is emulated in such detail by a great number of people except that of Muhammad, the Perfect Man “(Philip K. Hitti, (2005: 140).

Historical events played by prophet Mohammed is something ideal to be 
followed by Muslims. Thus, understanding the relations between the three religions will give a new awareness to the people of three faiths to reorganize the relations better. Structuring harmonious relations emerges from consciousness after understanding the life of the prophet with a sense of history. Awareness of history is an important part in the study of history which is also part of the basic teachings of the Qur'an (QS. Hud: 120) reveals the relations between religious communities at the time of Prophet Muhammad, as an exemplary figure of the human race, especially adherents of Islam, making Muslims realize that the Prophet never imposed its will in religion, and even showed respect for other religions. It's a form of respect by providing freedom to set its own laws of other religions, cooperation in economic and political fields with other authorities around the Arabian peninsula. Based on the description of the background, the principal issue that requires further investigation in this research is the inter-religious relations in the period of the prophet Muhammad.

\section{OVERVIEW OF GEOGRAPHICAL CONDITIONS AND SOCIO CULTURE OF THE PRE-ISLAMIC ARAB COMMUNITY}

Jazirah (Peninsula) in Arabic means 'island' so 'Jazirah Arab' means 'Island of Arabs'. The Arabs called their homeland a peninsula, even though only three parts only are bounded by the sea. Some historians called the Arab land "Shibhul jazirah" which in means "peninsula". To the west it is bordered by the Red Sea, to the south by the Indian Ocean, to the east by the Arabian Gulf (Persian Gulf) and to the north by the deserts of Iraq and the Sham Desert (Syrian Desert). The peninsula is approximately $1000 \mathrm{~km}$ long, and 1000 $\mathrm{km}$ wide (A. Syalabi, 2003: 28). Mecca in the book of Philip K. Hitti is called Macoraba by Ptolemy, taken from the language Saba, Makuraba, which means sacred place. This word indicates that Mecca was founded by a religious group, so that it can be said that since a long time ago, far before the birth of the Prophet, it has become a religious center. Mecca is located in Tihamah, south Hijaz, about 48 miles from the Red Sea (Philip K. Hitti, 2005: 130), located in a valley and hilly place as described in the Quran (Surah 14: 37) "a valley that has no plants "(Ministry of Religious Affairs, 2012: 260). Mecca served as a place of worship and also became a transit for the Arabs when they traveled to the North, and when they trade to the South, So Mecca has been a very strategic location connecting the two regions of the Northern and Southern Arabian Peninsula (Mardan, 2009: 5).

The people of Mecca were progressive and had succeeded in changing the trading city of Mecca into the center of prosperity. The city's prosperity could 
be drawn from a Meccan caravan engaged in a war of Badr (16 March 624). When the caravan returned from Gaza, the entourage comprised 1000 camels and according to al-Waqidi as quoted by Philip K. Hitti (2005: 130) the entourage was carrying merchandise worth 50,000 dinars. This illustrates the progress of the city of Mecca and its civilization which had been accomplished by the population of the city of Mecca in the sixth century AD. Overview of Mecca as the civilization center is also mentioned in the Quran as "Umm AlQura" (the capital) in Surat As Shura verse 7. The social conditions of Arab society can be seen in their treatment of women, slavery, and politics. Before the advent of Islam, women's rights were not recognized. They were oppressed, emasculated by the customary law. In the case of marriage, women were also oppressed. When a woman was married by her guardian, she had no right to give a reason, or rejection. The husband may divorce her at anytime. She did not have any power except waiting. Then, when her husband died, her stepchildren and her husband's relatives came to take the inheritace. She was also detained by her husband's family, and they treated her like a servant. The Arab society enslaved humans with the stroke of their sword. They made anyone a slave because of losing the war. Nobody dared talking about the system of slavery. In politics, the Arab community in Mecca, represented especially by the tribe of Quraish, owned establishment in politics. This can be seen in important positions held by Qushaiy ibn Qilab in the mid-fifth century AD in order to care for Kaaba (Jaih Mubarok, 2008: 25).

Religion historians argue that humans by nature like to think of religion and love of God, including the Arabs. History shows that the Arabian Peninsula, which is now comprised of barren deserts, were once lush and verdant earth that had provided the residents with a wide range of prosperity. Therefore, religious attachment had arisen in the Arab nation since long ago. They already had the concept of God. Ali Ahmad Said (Adonis) (2007: Ixxix) mentioned the theological characteristics namely the tendency of Arabs that overestimated in separating between man and God, and made the religious concept of God as a base and purpose, The dominant Arab thought was nothing but the thought of individuality (fardanah) abstract and very mystical (Muhammad Uthman Najati, 2010: 38).

\section{MECCAN PERIOD}

Prophet Muhammad was born in Mecca on 12 Rabi al-Awal in the year of elephant. Coinciding with the year 571 AD. According to an Egyptian astronomist, Mahmud al-Fakali Bsya, the date of birth of the Prophet, according to the science of Isyak, was on the 9th of Rabi al-Awal (M. Saribi, 1984:3). He 
was a descendant of Arab noble family, the Banu Hashim from Quraysh tribe, the tribe that was entrusted to maintain the Kaaba built by Prophet Abraham and his son (Ishmael). His father was Abdullah, the youngest son of Abdul Muttalib. Abdullah died before his son was born while his mother (Amina) died six years later (Jamil Ahmad, 2000: 2). For more detail, the Prophet's family tree can be seen in the following chart (Chart I).

Chart I. The family tree of Prophet Muhammad (Source: Ira Lapidus, 1999:30)

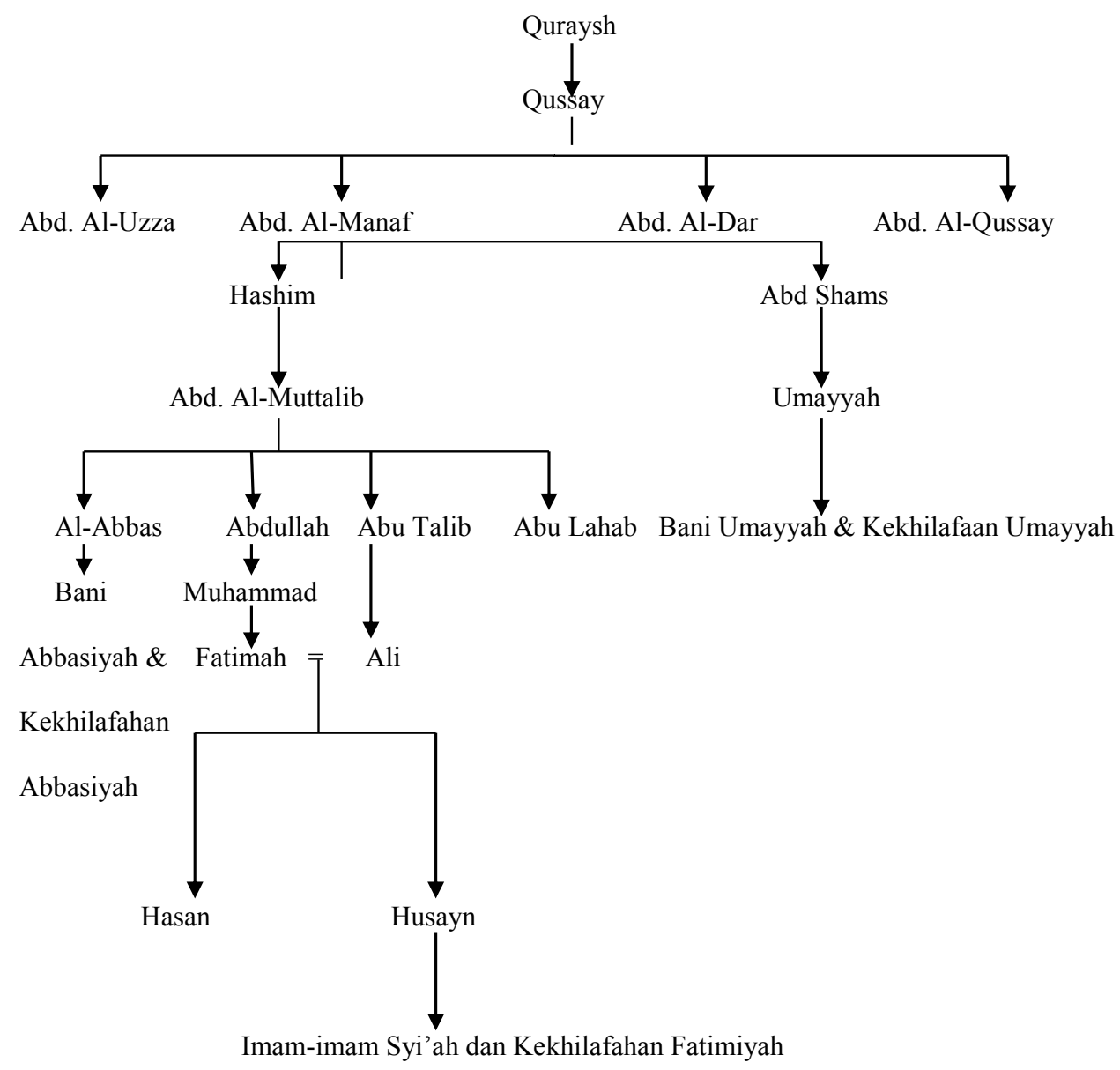

Sumber: Ira Lapidus, 1999:30

When Prophet Muhammad was born, the Arabs of Mecca were already acquainted with Christians. Every year people from outside Mecca flocked to the city to visit the seasonal markets, Ukkaz, a forum for Arab poets to hold a poetry competition for traders to offer their mercahndise (Shaykh Shafiyyurrahman al-Mubarakfuri, 2005: 26). Among the visitors, there were traders from Arab tribes who had converted to Christianity. In addition, traders of Quraysh themselves including Muhammad used to bring the caravan to go 
to a distant land, including Syria which most of the population were Christians and also to Habasyah (W. Montgomery Watt, 2007: 99). Muhammad had met with Christiana long before becoming a prophet. In Mecca, there were people from Africa, for example, from Abyssinia (Habasyah or Ethiopia), the king and the people embraced Christianity. at the age of 12, he was invited by his uncle, Abu Talib, to participate in the caravan to Syria. When the caravan arrived in Basra at the foot of Mount Draz (W. Montgomery Watt, 1984: 3), they passed the haven of merchants of Mecca. There stands a monastery inhabited by a Christian ministers from time to time. When the priest died, another priest replaced him and inherited all the wealth of the monastery, including all the ancient manuscripts. In these manuscripts, there is a prophecy about the coming of a prophet in the Arab society. Bahira, a priest who lived in the convent, completely mastered the content of this book (Muhammad Sa'id Ramadan al-Buthy, 1999: 34). The prophecy made sure that the prophet would come in his lifetime.

By the time Abu Talib and his entourage were on the way to approach the monastery, Bahira saw the cloud over Muhammad among the group of Quraysh who were with him. When the group of Abu Talib sheltered under a tree, Bahira saw twigs bend so as to shade Muhammad and his entourage under the tree (Abdul Aziz Ash-Syanawi, 2003: 12). Bahira said to the traveler: "O Quraysh! I have provided food for you. I wish you all come to me, young and old, slave or free "(Ahmad M. Sewang, 2006: 15). The Quraysh received the invitation of priest Bahira, except Muhammad, he was watching the camels and merchandise. As they approached, Bahira looked at their faces one by one. However, none of which he saw in accordance with the descriptions in his book; nor was there one among them that was appropriate for the greatness of two miracles. Perhaps, they had not entirely come.

Here's the next dialog:

Bahira said: "O Quraysh, do not let anyone of you left behind"

Quraysh replied: "No one gets left out, except for a boy!"

Bahira said: "Do not treat him like that, invite him here, let him be with us in this dinner party"

Abu Talib and others are blaming each other for their carelessness.

Someone said: "We are really damned! Son of Abd Allah was left behind and is not with us!"

Soon he met him and embraced him, and brought him to sit with the others (Martin Lings (Abu Bakr Siraj al-Din), 2007: 44) 
Ibn Ishaq said:

"When Bahira saw and noticed Muhammad he found some parts of his face and body match those described in the book. After they finished eating, the priest approached the youngest guests. Bahira felt confident, but he became convinced after seeing a prophetic sign exactly as described in his book "(Muhammad Sa'id Ramadan alButhi, 1999: 34).

Bahira then turned to Abu Talib and said:

... Take him back to his country, and keep him from the Jews. By Allah, if they see him as I do, they will kill him. Surely there will be something big in your brother's child. Therefore, they immediately took him back to his home. The same story was also expressed by Abdurrahman (1956: 44)

At the age of forty, Muhammad ibn Abdullah used to contemplate in the cave of Hira, just outside the city of Mecca. In that place he was praying, fasting, and giving alms to the poor. He was alarmed by what he felt was a crisis in the Arab society. In the last few decades, his tribe, the Quraysh, had become wealthy by trading in the neighboring countries. Mecca had become a city of commerce that was growing fast, but in an aggressive effort to get some of the wealth, the old values of the tribe were fading. Instead of protecting the weaker members of the tribe, as outlined in the rules governing the nomadic communities, now the tribe of Quraish wanted to make money by sacrificing some small groups of poorer tribal families. The strong were always right. Orphans and widows were unable to defend themselves. Women were despised and not worthy of respect (Abdul Wahid Khan, 2002: 17-18).

There was also a spiritual unrest in Mecca and throughout the peninsula. Arab people were aware that Judaism and Christianity, practiced in the kingdom of Byzantium and Persia, were more experienced than their pagan traditions. Some people believed that their Supreme Deity, Allah (whose name simply means "God"), was also revered by Jews and Christians; but He had not sent a prophet or a holy book for the Arabs in their own language. In fact, the Jews and the Christians often denounced Arabs because they were aside from God's plan. Throughout the Arab tribes, they fought each other, in a cycle of murder, revenge and retaliation. For many people in the Arab society, it appeared that the Arab nation was a missing race, always exiled from the civilized world and ignored by God himself (Karen Armstrong, 2002: 1-2). Hiwever, things changed on the night of 17 Ramadan in 611 AD, the angel Gabriel appeared before him, delivering God's revelation of the first surat of al-Alaq 1-5. 
When Prophet Muhammad received his first revelation above, he was worried about the consequences of what would happen to him in the Cave of Hira in that night, in which he met the Angel Gabriel. Khadijah, the wife of the Prophet said: "By Allah, Allah will never humiliate you as you always maintain good relations with people; you get used to facing big problems; you are always try to find new things (being creative, innovative); you always respect the guests; and you always help and side with the people who are trying to uphold truth, justice, and honesty (Didin Hafidhuddin, 2003: 75-76). Khadija went to Waraqa to share what they had just experienced. Waraqa said: "Blessed He, the Most Holy. By Him who holds the life of Waraqah. "Khadijah, believe me, he has received the Great Namus like what Moses received. Oh, it would be happy if I could go back into a strong youth, hopefully later I am still alive when your people throw you out" (Jafar H.M. Hadar, 1982: 18). According Waraqah's belief, all prophets and messengers of God faces challenges from society. For the call and message received by the Prophet is a prophetic appeal as occurred to the other Hebrew prophets mentioned in the Old Testament. The core teachings affirm that God is One. He is Omnipotent. He is the Creator of the universe. The Prophet delivered the Day of Judgment. Rewarded in heaven awaits those who carry out the orders of God, and a painful punishment in hell awaits those who ignore them (Philip K. Hitti, 2005: 141-142).

Islamic dakwa initially according to Muhaimin et al., (2005: 219) progressed through three stages: First, sirriyah or secretly (Patmawati, 2014: 5) aimed at the closest family members and friends, through a personal approach. This stage was done carefully, so as not to cause shock among the public, however, the results were quite adequate, proven by the fact some family members and closest friends managed to convert to Islam, such as Khadija, Ali bin Abi Talib, Zaid bin Harith, Abu Bakr, Uthman ibn Affan, Zubayr ibn al-Awam, Sa'ad bin Abi waqas, Abd al-Rahman ibn Awf, Talhah, Abu Ubaidah bin Jarrah, and Arqam ibn Abi al-Arqam. The latter's house was even used as a regular meeting place for those who converted to Islam; Second, it was conducted in semi-secret, in a sense that it was spread to wider family members or relatives, especially families who joined the clan of Bani Abdul Muttalib. As affirmed in the letter Ash-Syu'ara paragraph 214 (And give warning to your closest relatives). However, among them many who were not interested in Islam, even tried to leave the Prophet and mocked him. Among them was Abu Lahab. However, as for some of them, even though they did not accept Islam, in accordance with their tradition, they gave protection against a family member who received interference and insults from other clans. This occurred to Abu Talib and several other family members who were willing to fight for and defend the Prophet against the Quraysh, despite the difference in belief; 
Third, da'wah jahriyah or dakwa carried out openly after Umar ibn Khattab embraced Islam, where at first he was an enemy of Islam.

Changes in the dakwa methods from being secretly done to the open method caused a strong reaction from the people of Quraish, the group that was instrumental in the control of the city's life. The Quraish tribe not only worried about the challenge of the Prophet's religious traditions that are based on polytheism, but they felt that the basic structure of their society and their interests in the trade were also directly threatened by the new teachings that emphasize social justice, which later inluded more specifically the prohibition against usury and the obligation to pay zakat or alms for the poor. According to A. Syalabi (2003: 77-80), there are five causes that trigger the tribe of Quraysh to fight against the Prophet's teachings: Competition for power, equalization of rights between aristocratic caste and commoner, fear of day of resurrection, dogmatic to the ancestors, trade of sculptures.

The seventh month of the fifth year of Prophethood, 11 men along with four women set out for a journey to move away. Then, the next group followed up and the number who migrated to Ethiopia reached 70 people. Among them were Uthman bin Affan and his wife (Rukayya, daughter of the Prophet Muhammad), Zubayr ibn al-Awam, Abdurrahman bin Auf, Ja'far ibn Abi Talib, etc. They moved to secure the new religion they professed, and were even willing to leave their family behind in order to establish a new life in a foreign country. Religious ties are stronger than blood ties. In this way, the new religion threatened social order as well as replaced the old social order with the new one (Rianawati, 2010: 33). The arrival of the Muslims in Abyssinia was welcomed by King Negus. In fact, the King provided protection and allowed them to practice their Islamic religion. He also rejected a request from the Quraysh tribe to return the believers to Mecca.

In the tenth year of the prophethood or in the end of May or beginning of June $619 \mathrm{AD}$, the Prophet went to Thaif, within approximately sixty miles from Mecca. Prophet went to the Thaif on foot, and came home in the same manner. The Prophet accompanied by his assistant, Zaid bin Haritha. Every time he passed by a tribe, the Prophet invited them to Islam. But none of them listened to him. Arriving at Taif, the Prophet met three brothers of the leader of Bani Thaqif, namely Abd Yalail, Mas'ud and Hubaib, children Amr ibn Umair As-Thaqfy. The Prophet invited them to Allah, and to help Islam. However, the three refused the invitation. When he was about to go out of Taif, several bad people followed the Prophet, berating and screaming at him. They pelted the Prophet and Zaid, and two of them were wounded. They stopped pelting the Prophet, as the Prophet had reached the vineyard of Utbah and 
Syaibah, within three miles of Taif. Utbah and Syaibah had empathy to see the condition of the Prophet. They called their maid named Addas, adherent of Christianity. They sent Addas to give a bunch of grapes to the Prophet. When the Prophet received the grapes, he said:

"Bismillah" and then ate them.

"These words were never spoken by the population in this country" said Addas.

"From which country do you come from and what is your religion anyway?" Asked the Prophet.

"I’m a Christian from Nineveh" said Addas.

"From the land of the righteous, Yunus ibn Matta," said the Prophet.

"What did you know about the name of Yunus ibn Matta?" Asked Addas.

"He was my brother. He was a prophet, so am I ". Replied the Prophet. Addas immediately grabbed the head of the Prophet, kissed his hands and feet (Shafiyyurrahman Shaykh Al-Mubarakfury, 2005: 175).

From the event above, it shows that the Prophet took a position of responsibility for the community of the believers. The Prophet kept thinking about the means to protect them so that the teachings can reach the ears of those who potentially believe, and he can create social and political conditions for the expansion of the new religion (Islam) (Mohammed Arkoun, 1996: 70-71). After the event of Isra' and Miraj, a great development for the progress of the Islamic dakwa emerged. The development come from a number of residents of Yathrib who made pilgrimage to Mecca. They were comprised of Aus and Khazraj tribes (Badri Yatim, 2004: 24). They converted to Islam in three waves (A. Syalabi, 2003: 92-94) as follows:

a. In the tenth year of his Prophethood, several people of Khazraj came to Makkah for pilgrimage. The Prophet greeted them and introduced himself to them. Then, he held a meeting with them at al-Aqabah. In the meeting, they were summoned to the religion of Allah. The Prophet accepted their appeal. They accepted the Prophet's call. "Our tribe in Yathrib are hostile to each other. Never has a tribe in the world been as hostile as our people. And evil raged between them. In fact, we hope that, with you, they will be united by Allah again. We will get back to them. We will call them to this religion, hopefully with the help of Allah, they will be united to embrace this religion ". 
b. In the twelfth year of the Prophethood, an agreement was made which is known in history as the "Female Agreement", or "Aqabah Agreement" first. The treaty was called the female agreement, because there was a woman involved in it, namely Afra bint Abid ibn Tsalabah, and also referred to the Aqabah agreement as it happened in Aqabah. There were twelve men and one woman mentioned above coming to visit the Prophet. The meeting was held at al-Aqabah where they made a treaty with the Prophet.

When these people returned to Madinah, the Prophet sent Mus'ab ibn Umair with them. Mus'ab has been working diligently calling people to Islam in Yathrib so many commanders and leaders of Yathrib embraced Islam.

c. In the thirteenth year of the Prophethood, the second Aqabah Agreement was made. A series of events went as follows: there were 73 people of Yathrib visiting Mecca and making suggestions to the Prophet that the Prophet should migrate to Yathrib, and they would appoint him as prophet and leader.

Again they held a meeting with the Prophet at Aqabah. The Prophet was accompanied by his uncle, Abbas, who had not yet embraced Islam. After they were all seated, Abbas began the talk, and said:

"O the Khazraj! You all already know that Muhammad is one of our people. We have defended him, because he is honored and secured in his country. Now he wishes to side with you and join you. If you are really faithful to him in all things you have pointed out to him, and you will defend him from all those who challenged him, I will hand Muhammad to you, on your own responsibility. But in case you're going to hand him over to his enemies, and disappoint him, then leave him now. “

Khazraj replied:

"We have heard of what you said, O Abbas! Then let the Prophet himself speak. Take this opportunity, O Messenger of Allah, what you desire for yourself and your God! "

The Messenger of Allah said:

"I want to take the agreement of all of you, that you will guard me as you guard your family and your own children".

So they promised, they even promised to defend Muhammad with all their estate, or their leaders and noble people will be annihilated, and they would be willing to suffer all sorts of circumstances. Aqabah Agreement became the basis of hijrah of Prophet Muhammad (Jaih Mubarok, 2008: 45). Upon 
hearing the migration plan, the Quraysh planned to assassinate Prophet Muhammad. Responding to the plot of the Quraysh, the Prophet ordered the Muslims to migrate to Yathrib in advance and some friends along with the Prophet Muhammad launched a strategy that involved many parties so as to ensure smooth migration process and could foil the murder scheme planned by the Quraysh elites. Duringthe time in Mecca, the Prophet's activities were to strengthen faith formation and religious practice among Muslims. In Mecca, the Prophet faced opposition from many parties, even some of his followers were tortured to death. Nevertheless, following the creed of the Prophet remained firm and did not fade in the face of such opposition (Muhaimin et al., 2005: 218-219).

\section{MADINA PERIOD}

The event of migration (hijra) of Prophet Muhammad along with his companions had significant results in the life of the Muslim community, both in the theological and socio-cultural and political dimension. Theologically, hijra implies dissemination of dakwa and mobilized ukhuwah Islamiyah based on the teachings of God. Socio-cultural migration had a meaningful social and cultural transformation toward monotheism, while the migration itself was a politically reliable strategy of struggle.

Since the migration, Islam has spread to the entire Arabian Peninsula, even at a later time, has covered more than half the area on the earth's surface effectively, as the city of Medina where Muslims of Mecca emigrated to had similar spiritual roots with Islam, so that it allowed the acceptance of message of Islam. This acceptance had implications for social mobility of the Muslim community, giving people good fortune and Islam. This fact, of course, is related to the expertise of Prophet Muhammad in leading the Muslims in addition to his accommodation of social forces that existed at the time, including in his efforts to seek the support of Jews and several small local groups in Medina, and his perseverance in the face of the challenges of the struggle. It was also supported by the followers of the Prophet who were ready for self-sacrifice in the conduct of the apostolic mission carried out by the Prophet, which was demonstrated by the Ansar, the helpers, and the Muhajirin, the migrants.

During the period in Mecca, the Prophet Muhammad's position was still very weak as an oppressed minority group in the face of the power of the Quraysh. In contrast to the Medina period, the position of the prophet and Muslims went though great changes. Medina was considered a new birth of Islam after there was no room for preaching in Mecca for Muslims. Allah chose Medina as a pilot project for the formation of the first Islamic community. 
Medina indeed deserved to be a pilot area (Wahyu Ilahi \& Harjani Hefni, 2007: 55). Hijra changed the situation from darkness and helpless state to a strong and powerful state. In Medina, the Prophet openly preached for 10 years until his death. In Medina he organized his followers into a solid and disciplined society. Islam was free to spread. In Medina, the Prophet was not only the leader of the new faith, Islam, but also the leader of the Islamic State (Abdul Wahid Khan, 2002: 37-38). J. Suyuti Pulungan as quoted by Adeng Muchtar Ghazali (2004: 42-43) said that in politics, there are three main elements inherent to a group of people to be called a real community or political society, namely the existence of a particular region that binds them to live together and work together with a sense of security to develop the resources of their lives and practice their religion; social conscience to work together to achieve a common goal; and a legitimate political authority in the community capable of maintaining peace and promote the community. This authority is equipped with the institutional regulations applicable to individuals and each group. If the elements of the State specified in the Montevideo Convention (1933) are described, it will show the alignment as follows:

Elements of State and Madinah

\begin{tabular}{lll}
\hline No. & $\begin{array}{l}\text { Elements of the State in the } \\
\text { Montevideo Convention }\end{array}$ & The elements of the Medina State \\
\hline 1. $\quad$ Residential population. & $\begin{array}{l}\text { Residents of Yathrib (Madinah) con- } \\
\text { sisting of Muhajirin, Anshar, and } \\
\text { Jews. }\end{array}$ \\
\hline 2. $\quad$ Territory. & Yathrib or Medina and Mecca. \\
\hline G. Government & $\begin{array}{l}\text { Government of the Prophet, which } \\
\text { made the mosque a center of govern- } \\
\text { ment activities. }\end{array}$ \\
\hline & & $\begin{array}{l}\text { Relations with Abysinia (Ethopia), } \\
\text { Quraysh of Mecca, and other powers, } \\
\text { either peaceful relations or conflict } \\
\text { (war). }\end{array}$ \\
\hline
\end{tabular}

(Source: Jaih Mubarok, 2008: 53)

Starting with the response of Yathrib people who came to Mecca on pilgrimage month to appeal to the prophet, the progress cannot be separated from the personality of the prophet known as a man who never lied. The success of the prophet's dakwa can be seen in the attitude of people of Yathrib in the agreement of Aqabah I and II, where they were willing to change their 
attitudes and behavior, even willing to protect the prophet. Dakwa is basically a missionary attempt and a media to change people's behavior from negative to positive, and ignorant to be knoledgeable (Bahri M. Ghazali, 1997: 1). This is what the Prophet did to Yathrib society, forming a new society, and laying the foundations for a great society awaited by history.

Overall, the first Islamic state and the ideals of the State were established by Prophet Muhammad after he had migrated from Mecca to Medina. These ideals were not only in terms of how it functioned as a state and government, but also in terms of a series of events or actions performed by the Prophet Muhammad and his companions, especially the four Caliphs. Harun Nasution (1986: 92) said that those who migrated to Medina soon became a strong community and could stand alone. The Prophet immediately changed the name of the town, Yathrib, to Medina. The word "Medina" a root of "tamaddun" means civilization. The change describes determination, the people who aspired a civilized society. The formation of the people of Madina and then transformed into a state and government, was marked by the agreement written in 622 AD between the prophet and community groups in Medina. The written agreement is called Sahifah which is better known as the Medina Charter (misaq al-Medina). The full text of the Medina constitution is written in Sirat al-Nabawiyah of Ibn Hisham.

Regarding the basic principles contained in the Charter of Medina, experts differ in formulating it. Wahyu Ilahi and Harjani Hefni (2007: 59) put it into seven basic principles, namely: 1) Muslims and Jews live peacefully, freely professing and practicing the teachings of their respective religions. 2) Both the Jews and Muslims are obliged to bear their own costs. 3) If one of the parties fight the enemy, they shall assist the parties being attacked. 4) they should remind each other, and do good to each other, and shall not commit crime toward each other. 5) The Muslims and the Jews ought to help in implementing the obligations of mutual interest. 6) Yathrib becomes sacred land because of the text of this agreement. 7) Prophet Muhammad is the general leader for all the people of Medina. In the event of a dispute between the Muslims with the Jews, the solution is returned to the prophet as the highest leader in the medina to act as a decision make of the disputes.

Munawir Syadzali (former Minister of Religious Affairs) in Jaih Mubarok (2008: 49) mentioned that the fundamentals of the state contained in the Charter of Medina are: First, Muslims are one community (ummah) despite coming from diverse tribes; and second, the relations between members of the Islamic community and other communities are based on the following principles: (a) good neighborliness, (b) assisting each other in the face of common enemies, 
(c) defending those who are persecuted, (d) advising each other and (e) respecting religious freedom. Among the main principles of the Charter of Medina is the principle of cooperation among religious communities. The entire community regardless of religious background, ethnicity, and race, has to establish cooperation in building the community, but in the execution of religious rituals, each autonomous religious community has the right to perform the rituals of their own religion. The Medina Charter begins with the Preamble: In the name of Allah, Most Gracious, Most Merciful! It is the writing of Muhammad among the believers and Muslims of Quraysh and residents of Yathrib (Medina) and those who follow them, and given to them and fight with them. They are the one ummah that is different from the others (W. Montgomery Watt, 2007: 138).

In building a community of Medina, Muslims were encouraged to do good and to engage in cooperation with other people, as long as they were not hostile, combat and repel the believers from their country. It is in line with the words of God in al-Mumtahanah: 8-9. The Medina Charter is an agreement to set up various interests in a multi-ethnic, racial, and religious community. Many researchers believe that the Charter of Medina is a breakthrough and a modern achievement of the prophet. With the charter, the prophet was able to unite people who previously lived with fanaticism in their own tribes and clans, where hostility between one tribe and the other was very common. Noercholish Madjid (1983: 11) mentioned that:

\begin{abstract}
"The text of the Constitution was very interesting. It includes basic thoughts from the amazingly modern point of view. In the constitution, for the first time formulated ideas of a modern way of life, such as freedom of religion, the right of any group to organize according to their own life, independence of economic relations, etc. It also confirmed the existence of a general obligation, namely participation in the defense to face an external enemy."
\end{abstract}

In the first year of the Charter of Medina, social life was normal, to the purpose of the agreement. However, in second year, Jewish groups: Banu Qainuqa, Banu Nadir, and Banu Qaraiza, committed treason by collaborating with the Quraysh to fight the Prophet in Medina (Muhammad Sa'id Ramadan al-Buthi, 1999: 182). Obviously, such betrayal was a clear violation of the Charter of Medina they had signed. "In fact (nobody) should do bad things to his allies and defense must be given to those who have been persecuted." The betrayal was regarded as going to disturb social stability and as a consequence they 
were expelled from Medina in the seventh hijri year as the Prophet managed to conquer them (Muhammad Ahmad Assyria, 1997: 49). However, treason was seen by the prophet as a case that cannot be treated in general. Therefore, the Jews who remained faithful to the Charter of Medina were still treated well and able to stay in Medina safely.

Thus, the Medina Charter cannot be regarded as a failed treaty. Quite the opposite, in fact, with the charter the Prophet constitutionally had a legal basis for action against the treaty participants who committed treason that could create instability in Medina. In addition, the position of Muhammad as a prophet and political leader expanded by joining groups of other communities around the Medina and the Arabian Peninsula in general. Among those who forged a peace treaty with the Prophet was the Najran tribe, adherents of Christianity. The Prophet managed to establish a new state which was the State of Medina. The prophet was unanimously appointed as the head of state and was given the authority to lead and implement the state administration that has been agreed. So, in Medina he was a ruler who exercised political and military and religious power (Bernard Lewis, 2010: 80).

Maxime Rodinson quoted by M. Dawam Rahardjo (1982) described Prophet Muhammad as a "politician" caable of controling his feelings, and not allowing feelings that come out until the right moment; he could wait for long period of time but at the right time, he moved fast. "This can be seen in the Treaty Hudaybiya, i.e. the agreement between the Prophet and the Quraysh of Mecca, where the contents of the agreement seemed to harm the Prophet, but he accepted the contents of Hudaybiya Agreement. With the agreement, it signified that the Quraish of Mecca had acknowledged the prophet as a political leader of the Medina area. However, the Hudaybiya Agreement only lasted for two years. The Quraysh tribe of Mecca betrayed it, resulting in the event of Fath al-Mecca in the year $8 \mathrm{H}$ or $630 \mathrm{AD}$. The Prophet's love of peace can be seen in the events of Fath al-Mecca. The terms of peace made by the Prophet when conquering Mecca was an important event in the history of agreements between nations. No conqueror would offer such lenient terms to the defeated group, which was a mortal enemy, constantly harassing and slandering him. Even the biggest enemy, Abu Sufyan, the heinous leader of the Quraysh was left unharmed. When ten thousand trained Islamic soldiers attacked the Quraish of Mecca, the Prophet, with his sublime character and great spirit of tolerance, gave orders not to attack anyone. He stated, "Anyone who shelter at Abu Sufyan's house will be secured" (Jamil Ahmad, 2000: 3).

In the creation of the state of Medina, the Prophet served as an Apostle, statesman, legislator, moral enforcer, reformer, political expert, and economist. 
This integration, as quoted by J. Suyuti Pulungan, indicated that during his lifetime, Muhammad had successfully built Islam as a religion and as a harmonious state at the same time. In line with this, H.A.R. Gibbs said that at the time it was factual taht Islam was not only a religion, but was also capable of forming a free society, complete with the laws and specific governmental system (Adeng Muchtar Ghazali, 2004: 46-47).

\section{CONCLUSION}

Inter-religious relations in the period of the Prophet were harmoniously built and practiced. It can be seen in the cases of Priest Bahira with Abu Talib, Waraqa bin Naufal, King Negus in Habsyi (Ethopia), and the Christians who came from Bani Najran. Even though there were differences between the theology of religions, those differences did not weaken the good relations created in the form of an agreement for mutual respect and protection. The Medina Charter is proof that Prophet Muhammad was both a religious leader and a political leader. The Medina Cahrter was born ahead of its time and can be used as a source of inspiration for building a plural society. Through the Medina Charter, the Prophet successfully organized all ethnic and religious groups in Medina, uniting them as brothers, despite different religious and ethnic backgrounds, all having the same duty to defend the State of Medina should there be an attack from outside.

\section{REFERENCES}

Abdurrahman. 1956. Muhtasar Sirah Rasulullah saw. Beirut: Darul Arabiyah (transl.).

Ahmad, Jamil. 2000. Hundred Great Muslim (translated into Bahasa Indonesia as Seratua Muslim Terkemuka). Jakarta: Pustaka Firdaus.

Al-Mubarakfuri, Syaikh Shafiurrahman. 1997. Sirah Nabawiyah. Jakarta: Pustaka Al-Kautsar.

Amstrong, Karen. 2002. Muhammad Sang Nabi Sebuah Biografi Kritis (transl.). Surabaya: Risalah Gusti.

Ananda, Endang Basri. 1975. Cahaya Menjelang Subuh. Jakarta: Bulan Bintang.

Arkoun, Mohammed. 1996. Rethinking Islam. Yogyakarta: Pustaka Pelajar.

Asy-Syanawi, Abdul Aziz. 2003. Mengenal Kehidupan Rasulullah Saw. Yogya- 
karta: Mitra Pustaka.

Asyur, Muhammad Ahmad. 1977. Pidato-pidato Umar bin Khattab dan Pesan-pesannya. Bandung: Husaini.

Ghazali, Adeng Muchtar. 2004. Perjalanan Politik Umat Islam Dalam Lintasan Sejarah, Bandung: Pustaka Setia.

Ghazali, M. Bahri. 1997. Da’wah Komunikatif Membangun Kerangka Dasar Ilmu Komunikasi Dakwah. Jakarta: Pedoman Ilmu Jaya.

Hatta, Ahmad. (at all.). 2011. The Great Story Of Muhammad saw Referensi Lengkap Hidup Rasulullah saw Dari Sebelum Kelahiran Hingga Detikdetik Terakhir. Jakarta: Maghfirah.

Hadar, Ja'far H.M. 1982, "Menunggu Juru Selamat” in Panji Masyarakat, no. 347.

Hafidhuddin, Didin. 2003. Islam Aplikatif. Jakarta: Gema Insani.

Hitti, Philip K. 2005. History of The Arabs (transl). Jakarta: PT. Serambi Ilmu Semesta.

Ilahi, Wahyu \& Harjani Hefni. 2007. Sejarah Dakwah. Jakarta: Rahmat Semesta.

Khan, Abdul Wahid. 2002. Rasulullah di Mata Sarjana Barat. Yogyakarta: Mitra Pustaka.

Lapidus, Ira M. 1999. Sejarah Sosial Umat Islam. Jakarta: RajaGrafindo Persada.

Lings, Martin (Abu Bakr Siraj al-Din). 2007. Muhammad Kisah Hidup Nabi Berdasarkan Sumber Klasik. Jakarta: Serambi.

Madjid, Nurcholish (at all.). 1983. "Cita-cita Politik Kita". in Aspirasi Umat Islam Indonesia. Jakarta: Lembaga Penunjang Pembangunan Nasional (LEPPENAS).

Mardan. 2009. Al-Quran Sebuah Pengantar Memahami Al-Quran Secara Utuh. Jakarta: Pustaka Mapan.

Mubarok, Jaih. 2008. Sejarah Peradaban Islam. Bandung: Pustaka Bani Quraisy.

Muhaimin (at all.), 2005. Kawasan dan Wawasan Studi Islam. Jakarta: Kencana.

Najati, Muhammad Utsman. 2010. Psikologi Qurani Dari Jiwa Hingga Ilmu Laduni. Bandung: Marja. 
Patmawati. 2014. Sejarah Dakwah Rasulullah SAW Di Mekah dan Medina. in Al-Hikmah, Vol. 2. No.2. p: 37-59.

Rahardjo, M. Dawam. 1982. "Muhammad, Sang Nabi, Rasulullah”. in Panji Masyarakat, no.348.

Ramadhan al-Buthy, Muhammad Sa’id. 1999. Sirah Nabawiyah. Jakarta: Rabbani Press.

Rasyid, Daud. 1998. Islam Dalam Berbagai Dimensi. Jakarta: Gema Insani Press.

Rianawati. 2010. Sejarah Peradaban Islam. Pontianak: STAIN Press.

Said (Adonis), Ali Ahmad. 2007. Arkeologi Sejarah-Pemikiran Arab-Islam. Yogyakarta: LkiS.

Sayadi, Wajidi. 2013. Ilmu Hadis Panduan Memilah dan Memilih Hadis Sahih, Daif, Palsu dan cara Memahami Maksudnya Solo: Zadahaniva.

Sewang, Ahmad M. 2006. Hubungan Antar Umat Beragama (Bahasan Buku Sirat Nabawiyah Ibn Hisyam). Makassar: Universitas Islam Negeri (UIN) Alauddin Makassar.

Syalabi. 2003. Sejarah \& Kebudayaan Islam 1. Jakarta: Pustaka al Husna Baru.

Toisuta, Hasbollah (at all.). 2007. "Damai...Damai di Maluku...!” in Alpha Amirrachman (ed.). Revitalisasi Kearifan Lokal Studi Resolusi Konflik di Kalimantan Barat, Maluku dan Poso. Jakarta: International Center for Islam and Pluralism (ICIP).

Watt, W. Montgomery. 1984. Muhammad Nabi dan Negarawan. Jakarta: Kuning Mas. GLOSSIA

Yatim, Badri. 2004. Sejarah Peradaban Islam. Jakarta: Rajawali Pers. 